Review Article

\title{
The Impact of Government Efficiency, Corruption, and Inflation on Public Debt: Empirical Evidence from Advanced and Emerging Economies
}

\author{
Wei Ni Soh*, Haslinah Muhamad and Ong Tze San \\ School of Business and Economics, Universiti Putra Malaysia, 43400 Serdang, Selangor, Malaysia
}

\begin{abstract}
This research investigates the empirical relationship of government efficiency, corruption, and inflation regarding public debt between advanced and emerging economies. Random effects estimation is used to analyse a sample of 40 countries. The analysis results show that corruption and inflation in advanced economies have a significant and positive effect on public debt. Corruption affects public debt to increase, but on the flip side, inflation affects public debt to decrease. In emerging economies, the results show a positive impact of government efficiency on public debt. Hence, government efficiency will be considered an obstacle when a policy initiated to reduce public debt. Meanwhile, policymakers should take note countries' corruption and inflation rates when formulating policies to reduce public debt in advanced economies.
\end{abstract}

Keywords: Advanced countries, emerging countries, government efficiency, macroeconomics, public debt

ARTICLE INFO

Article history:

Received: 13 November 2020

Accepted: 11 June 2021

Published: 13 September 2021

DOI: https://doi.org/10.47836/pjssh.29.3.05

E-mail addresses:

sohweini@upm.edu.my (Soh Wei Ni)

hasm@upm.edu.my (Haslinah Muhamad)

tzesan@upm.edu.my (Ong Tze San)

*Corresponding author

\section{INTRODUCTION}

Global public debt accumulation has increased significantly and extensively since 2008 in economies, advanced and emerging (Fournier \& Bétin, 2018). In the past, the rise of public debt in advanced economies has been closely connected to wars and business cycle fluctuations (Abbas et al., 2011; Azzimonti et al., 2014). 
The aggressive borrowing of countries in covering the financial costs of war has led to high levels of debt-to-GDP ratio. During peacetime, the primary deficit due to stockflow adjustments has been the leading cause of debt rates surge. The rapid surge in global debt has drawn worldwide attention. Under certain circumstances, a large budget deficit or public debt may put the government at risk. The fiscal policies implemented during the sudden changes in the economic condition may be less significant when there is a large public debt (Hallerberg \& Wolff, 2008). At the same time, high public debt could suppress a country's economic growth (Herndon \& Pollin, 2014; Reinhart \& Rogoff, 2010). A large shadow economy and high corruption will cause debt to rise in a country (Cooray et al., 2017; Elgin \& Uras, 2013; González-Fernández \& González-Velasco, 2014). Simultaneously, high inflation in a country is also one of the causes of high debt levels (Cooray et al., 2017; Reinhart \& Rogoff, 2011). In summary of the mentioned literature, a high public debt country is more likely to have high corruption, high inflation, and high government efficiency. With the focus on government efficiency, the proposed study gives a new understanding of the mentioned literature by establishing empirical evidence on the effect of government efficiency on the public debt ratio in advanced economies and emerging economies.

Many countries likely depend on public debt to finance extra expenditures. Besides using public debt, the government finances the spending by reallocating private resources for public use. The government collects tax as a form of government revenue. When evaluating the government finance system, efficiency is one of the criteria. It measures the minimal loss of resources during the reallocation process and the decision of government spending. This evidence shows that government efficiency affects the government's decision in spending. Hauner and Kyobe (2008) claimed that an inefficient government tends to have high expenditures relative to the country's GDP. Besides, Heylen et al. (2013) show that a highly efficient government is better at reducing the public debt ratio at a given fiscal consolidation program in advanced economies. As the public debt is related to government efficiency, a set of 40 countries (contain advanced countries and emerging countries) have been selected to be tested for various relationships based on the country's economic growth stages. An advanced economy is a term used by the International Monetary Fund (IMF) to describe the most developed countries globally. Meanwhile, the IMF uses the emerging economy to describe a fast GDP growth economy.

According to World Bank (2018), the government efficiency of a country is measured based on the performance in wastefulness of government expenditure, transparency of policymaker and regulatory burden. Table 1 shows ten countries with the highest government efficiency index, their public debt, and debt-to-GDP ratio in 2018. Public debt is often quoted as debt to gross domestic product (GDP) as public debt only 
offers general information on how much a country owes. Debt-to-GDP provides an overview of debt sustainability, at which debt level to GDP is ideal for the country to pay back the debt owed (Escolano, 2010). On the other hand, a high debt-to-GDP may increase the burden of a country to pay the debt.

Table 1

Government Efficiency Index Ranking, 2018

\begin{tabular}{lccccc}
\hline Rank & Country & $\begin{array}{c}\text { Advanced } \\
\text { Economies } \\
/ \text { Emerging }\end{array}$ & Index ${ }^{1}$ & $\begin{array}{c}\text { Public Debt } \\
\text { (billions of } \\
\text { USD) }\end{array}$ & $\begin{array}{c}\text { Public Debt } \\
\text { (\% of GDP) }\end{array}$ \\
\hline 1 & Economies & & 1.86 & 58.43 \\
2 & Sierra Leone & Emerging & 5.77 & 79.33 & 75.60 \\
3 & Sweden & Advanced & 5.51 & 207.62 & 40.93 \\
4 & Russia & Emerging & 5.41 & 236.39 & 17.47 \\
5 & United & Advanced & 5.39 & 2301.44 & 87.03 \\
7 & Kingdom & Advanced & 5.37 & 469.76 & 56.66 \\
8 & Netherlands & Adverging & 5.59 & 156.05 & 61.37 \\
9 & Puerto Rico & Emerging & 5.34 & 53.92 & 54.57 \\
10 & Lithuania & Emerging & 5.22 & 17.30 & 36.52 \\
11 & Germany & Advanced & 5.20 & 2372.93 & 64.14 \\
\hline
\end{tabular}

Note:

${ }^{1}$ Government Efficiency index, scale ranges from 1 to 7.

${ }^{2}$ The table is tabulated based on the availability of data.

Source: World Bank (2018) and IMF (2018)

As shown in Table 1, United Kingdom (UK) and Germany have about USD 2,300 billion of public debt accumulated in 2018, with $87.03 \%$ and $64.14 \%$ of debt-to-GDP, respectively. They are ranked as the $5^{\text {th }}$ $($ Index $=5.39)$ and the $11^{\text {th }}($ Index $=5.20)$ respectively in the government efficiency index. The lower debt accumulation and debt-to-GDP would be Lithuania (USD
17.30 billion; $36.52 \%$ ), Puerto Rico (USD 53.92 billion; $54.57 \%$ ), Finland (USD 156.05 billion; $61.37 \%$ ), and Netherlands (USD 469.76 billion; $56.66 \%$ ). When all are compared with the UK, all of these countries show a lower government efficiency index. With an enormous debt accumulation, this raises a question: Does government efficiency reflect on the country's debt ratio? 
There is minimal empirical literature on how the quality of government efficiency affects the public debt level. As such, this study aims to investigate empirically whether government efficiency affects the level of debt-to-GDP ratio in both advanced economies and emerging economies.

\section{LITERATURE REVIEW}

Previous research shows different theories to analyse the level of public debt. Barro (1979) explains that governments run a budget surplus and budget deficit to reduce the sharp fluctuation of tax rates on citizens by using the tax smoothing approach. In other words, to maintain an almost constant tax rate for the benefit of citizens, the government is benevolent to change the budget over time between surplus or deficit. The model is then extended with the changes in price levels. He finds that the unanticipated inflation rate affects the nominal debt growth but not the actual inflation rate. Concerned about political decisions, Alesina and Tabellini (1990) argue that Barro's theory cannot explain the rapid public debt accumulation of industrial countries in peacetime and the differences between debt policies of countries with similar economic conditions. They believe that policymaker uses public debt to influence citizens' willingness to vote, where the public debt is higher if there is a disagreement between different policymakers. Moreover, Battaglini and Coate (2008) suggest that the level of public debt varies by implementing different fiscal policies. For example, the revenues obtained from tax income and borrowings provide public goods and pork-barrel spending. Therefore, the public debt level increases whenever there is an increase in the value of public goods or pork-barrel spending.

According to Escolano's (2010) public debt dynamics, public debt is determined based on the overall fiscal balances, primary balances, and interest bills. Debt at a point in time is equal to the difference between the interest of outstanding debt and primary deficit. The debt to GDP ratio is the summation of (i) the product of debt-lag and the differences between the effectiveness of the interest rate and nominal GDP; (ii) accumulation of primary deficit; and (iii) accumulation of residual stockflow adjustment. He suggests that the debt ratio changes due to the real terms, such as real interest rate, real growth, and fiscal adjustment. The inflation rate also affects the debt ratio as it lowers the real interest rate. However, high inflation will cause a high nominal interest rate which offsets the decrease in the actual value of debt.

According to Pareto's Efficiency theory (Pareto, 1906), efficiency is the condition where any further reallocation of resources is impossible since it will always make one individual better off and another worse off. As far as government spending is concerned, the most favourable condition is that reallocating the fund from one project to another leaves the first project in the worst position. On the other hand, inefficiency in allocating budget may lead to higher spending since the initial budget is no longer enough. When the existing budget from the 
revenue is insufficient to cover the higher spending, this causes a budget deficit which may contribute to debt accumulation.

Recently, many researchers study the government efficiency of countries by evaluating the socioeconomic indicators such as education spending of government, health spending of government, mortality, and fertility rate (Gupta \& Verhoeven, 2001; Hauner \& Kyobe, 2008; Tanzi \& Schuknecht, 1997). One reason is that the spending on social expenditure in a country is deemed the largest category of government spending. Furthermore, spending on education and health is believed to boost the economic growth (Tanzi \& Chu, 1998; Verhoeven et al., 1999). An efficient government spends or allocates the budgets in different public projects optimally in to maximise the output with minimal waste. These researchers suggest that a government with high spending is typically considered inefficient.

The empirical framework formulated in this study is based on prior research as follows. Government efficiency affects the public spending decision and fiscal policies in a country. The previous findings point out that high government efficiency is associated with a low debt ratio. However, if the country uses' policy to reduce the debt level, it is effective if the government efficiency is low. Using dynamic panel regression, Bergman et al. (2016) research the primary budget balance using the fiscal rule strength index and government efficiency index on 27 European Union (EU) countries from 1990-2012. They found a higher government efficiency has lower public debt level. However, their estimate shows that as government efficiency increases, the implemented fiscal rules help reduce public debt to a certain threshold and become a substitute for or complement government efficiency. A similar conclusion was put forward by Heylen et al. (2013). They use least squares estimation on 21 Organisation for Economic Co-operation and Development (OECD) countries from 1981 to 2008 and suggests that government wage bill cut contributes to a lower debt ratio when government efficiency is low. Nevertheless, it is found that consolidation programs are used, the more efficient the government is at reducing the debt ratio. A highly efficient country is believed to be "clean" and transparent in country's wealth management and debt management with lesser corruption.

Corruption is believed to hamper government efficiency and effectiveness leading to wasteful public spending (Liu et al., 2017; Montes \& Paschoal, 2016). The literature suggests the presence of corruption and shadow economy lead to a high level of debt ratio. González-Fernández and González-Velasco (2014) studies shadow economy, corruption, and public debt in Spain from 2000 to 2012 using a panel data approach. With corruption as the proxy of institutional quality, they state that corruption and shadow economy are the determinants of regional public debt accumulation in Spain. The government is forced to increase the debt level as a large shadow economy aggravates raising 
revenues for government finance. Evidence was also provided by Tarek and Ahmed (2017) in a regression estimation of governance and public debt accumulation of the Middle East and North Africa (MENA) countries from 1996 to 2015.

Governance is measured by Worldwide Governance Indicators which are (i) Political Stability, (ii) Absence of Violence index, (iii) Regulatory Quality index, (iv) Rule of Law index, (v) Control of Corruption index, (vi) Government Effectiveness index, and (vii) Voice and Accountability index. They suggest that poor governance will have a high debt level supported by three indicators: Regulatory Quality index, Rule of Law index, and the Political Stability and Absence of Violence index. Cooray et al. (2017) find that the higher the level of corruption, the more enormous the public debt amount of the country. On the other hand, in a dynamic panel regression between corruption and the expansion of public debt in a sample of 25 American states, Liu et al. (2017) found that by curbing public sector corruption, local governments can reduce public debt due to an increase in public sector efficiency. Similarly, Benfratello et al. (2018), in a cross-country analysis on corruption and public debt from 1995 to 2015, suggests that corruption increases public debt in a country. It was concluded that the effect is more robust in advanced economies and weaker in less-developed countries.

In the research on inflation and public debt, interesting suggestions are provided in the literature. Researchers believe that inflation will reduce the debt value in the actual term (Akitoby et. al., 2017). However, some argue that although the actual value of debt is reduced when there is high inflation, the interest payment is increased. Hence this causes the stock of debt to increase (Reinhart \& Rogoff, 2010). Studying the debt level increase in 44 countries, including advanced and emerging economies, Reinhart and Rogoff (2010) find that the linkage between inflation and public debt across advanced and emerging economies is different. In emerging economies, the high public debt level is connected to high inflation. Nevertheless, there is no relationship between the two variables in advanced economies. Cooray et al. (2017) use the inflation rate as a control variable in their research on the effect of corruption on public debt in advanced and emerging economies. They suggest that a high inflation rate is associated with a high debt-to-GDP ratio.

Besides the relationship between inflation and public debt, many researchers also focus their studies on inflation on reducing debt. Using debt dynamics, Reinhart and Sbrancia (2011) examined the relationship between inflation and debt in some advanced and emerging economies throughout 1945 to 2009 . They find that debt reduction using inflation is significant, particularly in advanced economics from 1945 to 1970 . Akitoby et al. (2017) study the impact of inflation on the debt-toGDP ratio in the Group of Seven (G7) countries with a series of regressions and concludes that a high inflation rate helps reduce public debt ratios in the case of 
advanced economies. However, a prolonged high inflation rate cannot solve high debt accumulation since high inflation negatively affects the countries, including reducing economic growth and household income. Hall and Sargent (2011), in their studies of debt developments in the US between 1941 and 2008 using debt dynamics, conclude that inflation and public debt are less significantly related.

\section{METHOD}

Based on the literature review above, descriptive research determines the relationship between government efficiency and public debt. Annual data between 2002 and 2018 of 40 countries are used in this study. The countries are chosen based on the GDP of the countries as well as the availability of data. All the chosen countries are grouped into advanced economies and emerging economies based on the IMF classification. The list of countries selected for this study is enclosed in Appendix 1.

\section{Measurement of Government Efficiency}

Data Envelopment Analysis (DEA) is a tool developed by Charnes et al. (1978) to assess the efficiency of decision-making units (DMUs) that have multiple inputs and outputs. DEA is a technique used to measure the productive efficiency of individual DMUs empirically. While closely related to production theory in economics, DEA is also an operations management benchmark. It selects a set of input-output vectors to evaluate the performance of manufacturing and service operations, particularly in the banking sector. In the situation of benchmarking, efficient DMUs, selected by DEA, may not essentially shape a "production frontier", but to a certain extent, it forms a "best-practice frontier" (Cook et al., 2014).

The efficiency score is generated based on a frontier by developing all the observed input-output vectors. The firm's efficiency is measured by the distance of its input-output vectors from the frontier. Thus, the virtual performance of all utilities in the sample can be compared. Subsequently, DEA will then be able to benchmark said firms against the best producers. This method assumes that if a firm can achieve a particular output level with a given input, another firm of the same size should achieve a similar output level.

Compared with other statistical methods, DEA has unique features that make it an excellent tool for evaluating firm efficiency. First, DEA does not require any assumptions on the relationships between inputs and outputs. Second, it is capable of managing multiple inputs and outputs, especially in performance measures. Third, it can be worked into a single mathematical model without specifications of trade-offs among multiple measures related to firm performance. The efficiency of government based on health expenditure has been investigated by a few researchers previously (Grigoli \& Kapsoli, 2013; Gupta \& Verhoeven, 2001; Hauner \& Kyobe, 2008). They suggest that the health sector is an important indicator to boost the growth in the economy, where it also determines government spending. In 
addition, corruption control in the health sector is also believed to be good due to lower spending (Mauro, 1998).

The notation is as follows:

$x_{g j}=$ input $g(g=1, \ldots, m), \operatorname{DMU} j(j=1, \ldots, n)$

$y_{h j}=$ output $h(h=1, \ldots, s)$

$a_{j}=$ no - negative weights attached to

DMU $j$ 's inputs and outputs

An output orientation is employed in this study. The agency conflict and cost issues have caused the role of corporate cash holdings to be questioned by stakeholders. Under these circumstances, stakeholders must know how much output can be produced if a firm improves its technical efficiency, given a fixed amount of inputs. Thus, an output orientation is an appropriate choice (Coelli et al., 1998). This method employs $F_{o}\left(x_{j}, y_{j}\right)=$ maximum $\varnothing$ to represent the output-oriented Farrell efficiency score that indicates the maximum possible expansion of output for DMU $j$.

The output-oriented DEA model is assumed to be associated with a maximisation of $\theta$ the subject to:

$$
\sum_{j=1}^{n} a_{j} y_{g j} \geq \emptyset y_{g j}, \mathrm{~g}=1, \ldots, \mathrm{s} \quad \text { (Equation i) }
$$$$
\sum_{j=1}^{n} a_{j} x_{h j} \leq x_{h j}, \mathrm{~h}=1, \ldots, m \text { (Equation ii) }
$$$$
a_{j} \geq 0, j=1, \ldots, n \quad \text { (Equation iii) }
$$

This model presumes a constant return to scale (CRS), as mentioned in the earlier research work of Charnes et al. (1978). The assumption is only preferable when all DMUs function at an optimum scale. The linear programming required in the DEA model is fulfilled for every DMU in the selected sample to attain its relative performance. The efficiency measure is collected as the inverse of the maximum proportional output that it can produce with the input level remaining consistent. The firm efficiency evaluated in this method defines a technical efficiency score from zero to one.

\section{Data and Analysis}

To analyse the relationship between government efficiency and public debt, the empirical model used in this study is specified as follows:

Public Debt it $=\beta_{0}+\beta_{1} G E_{i t}+\beta_{2}$ Corr $_{i t}+$ $\beta_{3} \operatorname{Inf}_{i t}+\beta_{3} D U M_{i t}+\varepsilon_{i t}$

where Public Debt is the debt-to-GDP ratio; $G E_{i t}$ is the index of government efficiency; Corr $_{i t}$ and Inf $f_{i t}$ represent corruption and Inflation. The $D U M_{i t}$ represents the advance and emerging economy, which only appears in the pooled result. The $\varepsilon_{i t}$ is the random error term. Panel Data regression is used to examine the empirical model. The best regression model will be chosen from the Pooled Model, the Random Effects Model, or the Fixed Effects Model to determine the linear relationship between the public debt and efficiency. Breusch and Pagan Lagrangian multiplier (BP-LM) and Hausman Tests were performed, and the result is illustrated in Table 2. 
Table 2

BP-LM Test and Hausman Test for the three models

\begin{tabular}{lcccc}
\hline & & BP-LM Test & Hausman Test & Result \\
\hline Model & I & $2169.24^{* * *}$ & 2.630 & Random effect \\
& & $(0.000)$ & $(-0.453)$ & \\
Model & II & $1217.89^{* * *}$ & 2.770 & Random Effect \\
& & $(0.000)$ & $(-0.428)$ & \\
Model & III & $843.25^{* * *}$ & 1.480 & Random effect \\
& & $(0.000)$ & $(-0.688)$ & \\
\hline
\end{tabular}

Note: p-values are in parenthesis. $* * *$ denotes significant at $5 \%$.

Since there is heterogeneity in the model, another test, the Hausman test is adopted to identify whether the fixed effects model or random-effects model is suitable.

H0: Random-effects model

H1: Fixed effects model

Decision: Rejects H0 if the p-value is less than 0.05 significant level. Otherwise, accept $\mathrm{H} 0$.

The dependent variable in this study is the country's debt-to-GDP ratio (Cooray et al., 2017; Heylen et al., 2013; Tarek \& Ahmed, 2017). The time-series data on the historical public debt ratio for each country is provided in the IMF database. It is measured in the percentage of GDP of the country. IMF estimates several countries' public debt ratios throughout the year 2018.

The primary independent variable used in this study is government efficiency. Government efficiency is determined using DEA, with the score range between 0 to 1. Thus, a high index is indicating the greater efficiency of government. When a government is efficient, it is believed to have lower spending and the least waste from the inputs bringing less debt to the country. Therefore, a negative coefficient is expected from the analysis.

Corruption Perceptions Index (CI) is another independent variable tested in this study. This index is collected from Transparency International. The data ranges from 1995 to 2018. It is often used as a proxy for analysis of cross-country analysis (Benfratello et al., 2018; Cooray et al., 2017). From 1995 to 2011, CI is measured from 0 to 10 , where 0 ranked the country as highly corrupted, and 10 is without any corruption. Since 2012, the score scale has changed from 0 to 100 , where 0 is ranked highly corrupted, and 100 is without any corruption. Therefore, the index is adjusted to a scale of 0-100 in this study. In addition, the original CI is inverted in this study for a direct indication, where 0 indicates a country without any corruption. In contrast, 100 indicates the country with the highest corruption. Corruption of government reflects the abuse of power in the public 
sector for personal benefit. It comes in different forms, such as bribery and political corruption. An increase in corruption causes the original budget to be insufficient for government finance spending. Therefore, a positive coefficient for the relationship is expected from the analysis.

Based on previous research, the inflation calculated by percentage change of the Consumer Price Index (CPI) is selected as the next independent variable for this study (Benfratello et al., 2018; Cooray et al., 2017; González-Fernández \& González-Velasco, 2014; Heylen et al., 2013; Wang et al., 2017). Inflation data is collected from the World Bank database. Mixed conclusions are suggested by previous researchers on the relationship between inflation and public debt. The rising price of tax collected during high inflation will help reduce the actual value of debt in a country. Indeed, inflation erodes the value of debt in the actual term. However, the value of interest payment is believed to increase, leading to a higher debt value. However, from the previous studies, the relationship between inflation and public debt remains unclear. It may also vary according to the country's income. Therefore, either a positive or negative coefficient is expected from the analysis.

The countries tested in this paper are categorised according to the dummy variable. Countries under advanced economies are labelled as 0 ; countries that are emerging economies are labelled as 1 . Thus, some 20 advanced economies and 20 emerging economies are used in this study. Panel regression, either fixed or random effect, has been employed for the second stage analysis to determine the relationship between all variables on the public debt.

\section{RESULTS AND DISCUSSIONS}

\section{Descriptive Analysis}

The analysis start with the regression between government efficiency and public debt across the sample (Model I), in all 40 countries, regardless of their identification as advanced or emerging economies. Then, the analysis is focused on the relationship between government efficiency and public debt based on the identification of each country, either advanced economies (Model II) or emerging economies (Model III).

Table 3 presents the descriptive statistics for the whole sample and two other samples, which are broken down by country identification, advanced economies, and emerging economies. The mean value of the debt-to-GDP ratio for the countries under investigation is 52.4150, where advanced economies have a higher mean value (64.4005) than emerging economies (40.3227). The maximum value of debt to GDP ratio of advanced economies is also higher than emerging economies. The standard deviation of the public debt ratio is higher in advanced economies (27.5409) than in emerging economies (20.9563), suggesting that the 20 advanced economies have a more diverse value of the debt-toGDP ratio.

Government efficiency is the efficiency score calculated in this study using DEA, on a scale of 0 (least efficient) to 1 (most efficient). The mean value of government 
efficiency for the 40 countries under investigation is 0.6132 . One interesting feature from the descriptive statistics is that emerging economies have a higher government efficiency score (0.7271) than advanced economies (0.5201). The results are consistent with the previous studies (Hauner \& Kyobe, 2008) on government efficiency using either data envelopment analysis (DEA), public sector performance (PSP), or public sector efficiency (PSE) methodology.

The mean value of corruption for the whole sample is 42.9263 . The mean value is lower in advanced economies (22.3842) and higher in emerging economies (63.6512). Previously, researchers found that the structure of the government is one of the determinants of corruption in a country (Kim et al., 2017; Shleifer \& Vishny, 1993). A country with strong democracy that emphasises the participation of citizens, such as Switzerland or Australia, has low corruption. Moreover, non-democratic countries such as Singapore and Hong Kong are numerous countries with the lowest corruption due to the strong anticorruption institution (Transparency International, 2019). Thus, this implies that advanced economies have better corruption control. Based on the standard deviation of corruption, the heterogeneity in corruption for advanced and emerging economies is similar.

Table 3

Descriptive statistics of Debt-to-GDP ratio, Government Efficiency, Corruption Perception Index and Inflation on selected countries between 2002 and 2018

\begin{tabular}{lccccc}
\hline Variables & N & Mean & SD & Min. & Max. \\
\hline Whole Sample (Model I) & & & & & \\
$\quad$ Debt to GDP ratio & 677 & 52.4150 & 27.2728 & 1.5620 & 132.0390 \\
Government Efficiency & 545 & 0.6132 & 0.2436 & 0.1610 & 1.0000 \\
$\quad$ Corruption Perception Index & 677 & 42.9263 & 24.3115 & 1.0000 & 90.0000 \\
$\quad$ Inflation & 680 & 4.0681 & 4.6835 & -4.4781 & 54.4002 \\
Advanced Economies (Model II) & & & & & \\
Debt to GDP ratio & 340 & 64.4005 & 27.5409 & 9.7020 & 132.0390 \\
$\quad$ Government Efficiency & 300 & 0.5201 & 0.2163 & 0.1610 & 1.0000 \\
$\quad$ Corruption Perception Index & 340 & 22.3842 & 13.2947 & 1.0000 & 61.0000 \\
$\quad$ Inflation & 340 & 1.7787 & 1.3012 & -4.4781 & 6.6280 \\
Emerging Economies (Model III) & & & & & \\
$\quad$ Debt to GDP ratio & 337 & 40.3227 & 20.9563 & 1.5620 & 96.3520 \\
Government Efficiency & 245 & 0.7271 & 0.2265 & 0.1780 & 1.0000 \\
$\quad$ Corruption Perception Index & 337 & 63.6512 & 12.3697 & 25.0000 & 90.0000 \\
$\quad$ Inflation & 340 & 6.3575 & 5.6329 & -1.5448 & 54.4002 \\
\hline
\end{tabular}


The mean value of inflation for all 40 countries is 4.0681. Advanced economies have lower inflation (1.7787) than emerging economies (6.3575). Keeping inflation low has been a significant macroeconomics challenge. It is generally believed that high and volatile inflation hurts economic growth. However, inflation is not solely determined by one factor. The source of inflation is also very diverse in different countries (Loungani \& Swagel, 2001). Factors such as corruption, economic crisis, exchange rate regime, oil price crisis, monetary growth, and political instability could also affect the inflation rate differently. Based on collected data, in 2002, Turkey experienced high inflation that is $54.4002 \%$ which is a generally high inflation rate in the group of emerging economies. In addition, there is a higher standard deviation in inflation in the group of emerging economies (5.6329). It suggests that inflation is more heterogeneous in emerging economies than in advanced economies.

Table 4 presents the Pearson correlation between all the variables of this study. The table reveals that government efficiency, corruption, and inflation are negatively correlated with the debt-to-GDP ratio, with the values of $-0.2116,-0.2750$, and -0.2527 , respectively.

Table 4

Pearson correlations

\begin{tabular}{lcccc}
\hline Variables & $\begin{array}{c}\text { Debt to GDP } \\
\text { ratio }\end{array}$ & $\begin{array}{c}\text { Government } \\
\text { Efficiency }\end{array}$ & Corruption & Inflation \\
\hline $\begin{array}{l}\text { Debt to GDP } \\
\text { ratio }\end{array}$ & 1.0000 & - & - & - \\
Government & $-0.2116 * * *$ & 1.0000 & - & - \\
Efficiency & $(0.000)$ & & 1.0000 & - \\
Corruption & $-0.2750 * * *$ & $0.4024 * * *$ & & 1.0000 \\
& $(0.000)$ & $(0.000)$ & $0.5352 * * *$ \\
Inflation & $-0.2527 * * *$ & $0.2563 * * *$ & $(0.000)$ & \\
& $(0.000)$ & $(0.000)$ & & \\
\hline
\end{tabular}

Note: p-values are in parenthesis. $* * *$ denotes significant at $5 \%$.

The correlation between government efficiency and corruption is 0.4024 , statistically significant at 0.05 significant level. The same goes for the correlation between government efficiency and inflation, a statistically significant correlation of
0.2563 . Thus, both of the variables have a positive correlation with government efficiency. Inflation and corruption have the highest correlation values among all the variables, with 0.5352 of correlation, statistically significant at 0.05 . 


\section{Regression Analysis}

The regression analysis (Table 5) on the relationship between public debt and the independent variables (government efficiency, corruption, inflation, and dummy variable) is started by estimating the whole sample, as Model I. Then, the analysis focuses on the effect of independent variables (government efficiency, corruption, and inflation) on public debt in different subsamples, according to the classification of the countries. A group of countries identified as advanced economies forming Model II; Model III is formed by emerging economies. Based on the BP-LM and Hausman Tests, random-effects regression is more suitable for all three models. A Driscoll-Kraay standard error (1998) panel random effects estimate the models due to heteroscedasticity and autocorrelation in the data.

Table 5 reports the results of the regression on government efficiency and public debt. The model I shows that government efficiency negatively affects public debt, but the relationship is not significant. Although government efficiency is computed based on limited available data, its effect on the public debt ratio is expected despite the smaller sample size. For example, Model I suggest that a 1-unit increase in government efficiency decreases the public debt ratio by 0.5318 . The insignificant result leads to a further investigation by focusing the analysis on different sub-samples, including advanced economies (Model II) and emerging economies (Model II).

Table 5

Regression results of the relationship between government efficiency and public debt on selected countries from 2002 to 2018

\begin{tabular}{lccc}
\hline \multirow{2}{*}{ Variables } & \multicolumn{3}{c}{ Dependent variable: Debt-to-GDP ratio } \\
\hline Government Efficiency & $\begin{array}{c}\text { Model I } \\
\text { (Whole Sample) }\end{array}$ & $\begin{array}{c}\text { Model II } \\
\text { (Advanced } \\
\text { Economies) }\end{array}$ & $\begin{array}{c}\text { Model III } \\
\text { (Emerging } \\
\text { Economies) }\end{array}$ \\
\hline Corruption & -0.5318 & -7.9211 & $8.7459^{* *}$ \\
& {$[-0.1000]$} & {$[-1.3700]$} & {$[2.7400]$} \\
& $(0.9200)$ & $(0.1900)$ & $(0.0150)$ \\
Inflation & $0.7254^{* * *}$ & $1.1730^{* *}$ & 0.2699 \\
& {$[4.4800]$} & {$[2.8100]$} & {$[1.5900]$} \\
& $(0.0000)$ & $(0.0130)$ & $(0.1340)$ \\
& 0.0436 & $-4.3819 * *$ & 0.3367 \\
& {$[0.1200]$} & {$[-2.8500]$} & {$[1.6700]$} \\
& $(0.9090)$ & $(0.0120)$ & $(0.1150)$ \\
\hline
\end{tabular}


Table 5 (Continued)

\begin{tabular}{lccc}
\hline \multicolumn{3}{c}{ Dependent variable: Debt-to-GDP ratio } \\
\hline Variables & $\begin{array}{c}\text { Model I } \\
\text { (Whole Sample) }\end{array}$ & $\begin{array}{c}\text { Model II } \\
\text { (Advanced } \\
\text { Economies) }\end{array}$ & $\begin{array}{c}\text { Model III } \\
\text { (Emerging } \\
\text { Economies) }\end{array}$ \\
\hline Dummy & $-54.9263^{* *}$ & - & - \\
& {$[-2.2500]$} & - & - \\
No of Countries & $(0.0390)$ & - & - \\
Observation & 40 & 20 & 20 \\
$\mathrm{R}^{2}$ & 542 & 300 & 242 \\
Wald chi-square & 0.2035 & 0.1686 & 0.004 \\
$p$-value & 56.43 & 16.03 & 12.31 \\
\hline
\end{tabular}

Note: Significant at $1 \%(* * *), 5 \%(* *)$ and 10\% (*); t-values are in square brackets, p-values are in parentheses.

Model II suggests that in advanced economies, as the government efficiency increased by 1 -unit, the public debt ratio is reduced by 7.9211. Thus, government efficiency and public debt have a negative statistically insignificant relationship. It may be the reason for the insignificant relationship in Model I. However, the direction of the relationship between government efficiency and public debt remains unclear. The debtto-GDP ratio in descriptive statistics (Table 3) shows that advanced economies have a much higher mean debt-to-GDP ratio than emerging economies, more than 24.0778.

Surprisingly, the results for emerging economies tested in Model III differ from expectation. Government efficiency has a positive and statistically significant relationship with public debt in emerging economies. A country with a high government efficiency has a high debt ratio. A 1-unit increase in government efficiency increases public debt by 8.7459 in emerging economies, which is significant at $5 \%$. This direction of the relationship is unaccepted. However, some possible explanations can be found in previous studies. Hauner and Kyobe (2008) suggest that emerging economies with a low GDP facing rapid growth increases their efficiency, which primarily affecting socialeconomic growth. This growth is also shown to be accompanied by an increase in the government's spending. Therefore, the country will have to increase the spending in the social sector to improve government efficiency. Another conclusion put forward by Bergman et al. (2016) is that the negative relationship between government efficiency and government spending is only valid before government efficiency reaches a minimum threshold level. Above that, they will become a 'complement' to each other. The relationship is further investigated by 
Heylen et al. (2013). They find that to cut the debt in a country, reducing government spending is not effective if the government efficiency is high.

For corruption and public debt ratio, the relationship shown in Model I is in line with previous findings, which is positive and significant (Benfratello et al., 2017; Cooray et al., 2017; GonzálezFernández \& González-Velasco, 2014; Liu et al., 2017). A similar result is shown in advanced economies, where corruption and public debt have a significant and positive relationship. The results clearly explain that corruption indeed contributes to the increase of public debt in all countries. The high spending in advanced economies may cause a substantial effect between corruption and public debt (Benfratello et al., 2017). However, for emerging economies, the positive relationship between corruption and public debt is not significant. Corruption may affect the public debt accumulation in emerging economies, but somehow it is not obvious. It is in line with the results provided by Benfratello et al. (2017), where the effect of corruption on public debt is weaker in emerging economies. The public debt in emerging economies may be caused by corruption, but other external factors can lead it to increase (Benfratello et al., 2017; Panizza, 2008).

The effect of inflation on the public debt ratio in Model I is negative and statistically insignificant. The relationship is reconfirmed in Model II and Model III. In advanced economies, the relationship between inflation and the public debt ratio is negative and significant. As inflation increases in advanced economies, the debt accumulation is reduced. The real value of debt is reduced in a country when inflation is high, as the tax revenue collected by the government is higher due to inflation (Akitoby et al., 2017; Reinhart \& Rogoff, 2011). Akitoby et al. (2017) conclude that high inflation is an effective tool to reduce debt in a country. Empirical evidence supported by Reinhart and Sbrancia (2011) that inflation effectively reduce debt, especially in advanced economies. As inflation increases in the current period, the original amount of debt owed in the previous period is worth lesser in the current period due to the lower absolute value of money.

Hence, the public debt ratio is lower with higher inflation. In emerging economies, the relationship between inflation and the public debt ratio is favourable and insignificant. Inflation reduces the actual value of debt in a country, yet different conclusions are putting forward in past studies. For instance, Reinhart and Rogoff (2011) suggested that inflation causes the interest payment on debt to increase, leading to higher debt in the country. On the other hand, some researchers found that inflation and public debt have no significant relationship (Giannitsarou \& Scott, 2006; Hall \& Sargent, 2011). Thus, inflation may affect the public debt accumulation in emerging economies, but the effect is not obvious.

\section{CONCLUSION AND RECOMMENDATION}

The main objective of this study is 
to provide empirical evidence on the relationship of government efficiency, corruption, and inflation regarding public debt between advanced and emerging economies. The estimates suggest that government efficiency on public debt varies by country's classification. The relationship between government efficiency and public debt is statistically significant and positive in emerging economies. It implies that government efficiency contributes to increasing public debt in emerging economies. However, the relationship is unclear in advanced economies due to the insignificant coefficient. However, the results show that public debt in advanced economies is affected by corruption and inflation. High corruption will lead to high debt in advanced economies, while high inflation will reduce debt. Whereas in emerging economies, corruption and inflation have no relationship with public debt.

The following suggestions can be drawn from this study. First, governments should consider government efficiency in decreasing sizeable public debt, especially in emerging economies. An increase in government efficiency not only improves the quality of government by reducing the waste from spending, but it also helps in economic development. Hauner and Kyobe (2008) advise that government efficiency is essential for a country to be more prosperous. However, an increase in government efficiency, particularly in social expenditure, may, in turn, cause the public debt accumulation to increase-in the case of emerging economies. In advanced economies, although there are no significant results from this study between government efficiency and public debt, corruption and inflation seem to affect the considerable debt accumulation.

The statistics illustrated in Table 3 show that the overall advanced economy has a high corruption index, lower government efficiency, and lower inflation than the emerging economy. The IMF and reviews have investigated this serious corruption situation in the advanced economy. The advanced countries involved in bribery and other forms of corruption as part of a revised framework on governance around the world will be monitored based on the corruption. The results in Table 5 provide statistical evidence on the positive relationship between corruption and public debt for the advanced economy at a 5\% significant level. It debates the findings in the existing literature, which show that in advanced economies, a high efficient government is not performing better in reducing the public debt ratio (Heylen et al., 2013). People always think that advanced economies should have lower corruption and high government efficiency. However, this fact is not supported by statistical evidence in this study. Nevertheless, this study is supporting findings in Cooray et al. (2017), Elgin and Uras (2013), and González-Fernández and González-Velasco (2014), which shows that high corruption will increase the public debt for a country. In summary, the relationship between public debt, corruption, and inflation will 
vary according to a country's growth and development stage.

A considerable accumulation of public debt has been a significant macroeconomics issue. However, managing public debt is a challenging task for a country. Moreover, since reducing public debt takes a long time, different economic variables should be considered to reduce public debt effectively.

\section{ACKNOWLEDGEMENT}

The authors would like to thank their colleagues who have provided them with professional support. Nevertheless, the author would also like to thank friends, family members, and anyone else who supported them during the process.

\section{REFERENCE}

Abbas, S. A., Belhocine, N., El-Ganainy, A., \& Horton, M. (2011). Historical patterns and dynamics of public debt - Evidence from a new database. IMF Economic Review, 59(4), 717-742.

Akitoby, B., Binder, A., \& Komatsuzaki, T. (2017). Inflation and public debt reversals in the G7 countries. Journal of Banking and Financial Economics, 1(7), 28-50.

Alesina, A., \& Tabellini, G. (1990). A positive theory of fiscal deficits and government debt. The Review of Economic Studies, 57(3), 403-414. https://doi.org/10.2307/2298021

Azzimonti, M., De Francisco, E., \& Quadrini, V. (2014). Financial globalization, inequality, and the rising public debt. American Economic Review, 104(8), 2267-2302.

Barro, R. J. (1979). On the determination of the public debt. Journal of Political Economy, 87(5), 940-971.
Battaglini, M., \& Coate, S. (2008). A dynamic theory of public spending, taxation, and debt. American Economic Review, 98(1), 201-236.

Benfratello, L., Del Monte, A., \& Pennacchio, L. (2018). Corruption and public debt: A crosscountry analysis. Applied Economics Letters, 25(5), 340-344.

Bergman, U. M., Hutchison, M. M., \& Jensen, S. E. H. (2016). Promoting sustainable public finances in the European Union: The role of fiscal rules and government efficiency. European Journal of Political Economy, 44, 1-19. https://doi. org/10.1016/j.ejpoleco.2016.04.005

Coelli, T. (1998). A multitage methodology for the solution of orientated DEA models. Operations Research Letters, 23, 143-149. ht tp://dx.doi.org/10.1016/S01676377(98)00036-4

Cook W. D., \& Joe Z. (2014). DEA for two-stage networks: Efficiency decompositions and modeling techniques. Data Envelopment Analysis, 1-29.

Cooray, A., Dzhumashev, R., \& Schneider, F. (2017). How does corruption affect public debt? An empirical analysis. World development, 90, 115-127. https://doi.org/10.1016/j. worlddev.2016.08.020

Elgin, C., \& Uras, B. R. (2013). Public debt, sovereign default risk and shadow economy. Journal of Financial Stability, 9(4), 628-640.

Escolano, M. J. (2010). A practical guide to public debt dynamics, fiscal sustainability, and cyclical adjustment of budgetary aggregates. International Monetary Fund.

Fournier, J. M., \& Bétin, M. (2018). Sovereign defaults: Evidence on the importance of government effectiveness (No. 1494). OECD Publishing.

Giannitsarou, C., \& Scott, A. (2006). Inflation implications of rising government debt (No. 
w12654). National Bureau of Economic Research.

González-Fernández, M., \& González-Velasco, C. (2014). Shadow economy, corruption and public debt in Spain. Journal of Policy Modeling, 36(6), 1101-1117.

Grigoli, F., \& Kapsoli, M. J. (2013, August 28). Waste not, want not: The efficiency of health expenditure in emerging and developing economies (No. 13187). International Monetary Fund. https://www. imf.org/en/Publications/WP/Issues/2016/12/31/ Waste-Not-Want-Not-The-Efficiency-of-HealthExpenditure-in-Emerging-and-DevelopingEconomies-40899

Gupta, S., \& Verhoeven, M. (2001). The efficiency of government expenditure: Experiences from Africa. Journal of policy modeling, 23(4), 433467.

Hall, G. J., \& Sargent, T. J. (2011). Interest rate risk and other determinants of post-WWII US government debt/GDP dynamics. American Economic Journal: Macroeconomics, 3(3), 192-214.

Hallerberg, M., \& Wolff, G. B. (2008). Fiscal institutions, fiscal policy and sovereign risk premia in EMU. Public Choice, 136(3-4), 379396.

Hauner, D., \& Kyobe, A. (2008, September 1). Determinants of government efficiency (No. 2008-2228). International Monetary Fund. https://www.imf.org/en/Publications/WP/ Is sues/2016/12/31/Determinants-ofGovernment-Efficiency-22296

Herndon, T., Ash, M., \& Pollin, R. (2014). Does high public debt consistently stifle economic growth? A critique of Reinhart and Rogoff. Cambridge Journal of Economics, 38(2), 257-279.

Heylen, F., Hoebeeck, A., \& Buyse, T. (2013). Government efficiency, institutions, and the effects of fiscal consolidation on public debt. European
Journal of Political Economy, 31, 40-59. https:// doi.org/10.1016/j.ejpoleco.2013.03.001

IMF (2018). Public debt. https:// https://www.imf. org/en/Data

Liu, C., Moldogaziev, T. T., \& Mikesell, J. L. (2017). Corruption and state and local government debt expansion. Public Administration Review, 77(5), 681-690.

Loungani, M. P., \& Swagel, M. P. (2001, December). Sources of inflation in developing countries (Working Paper No. 1-198). International Monetary Fund. https:/www.imf. org/external/pubs/ft/wp/2001/wp01198.pdf

Kim, E., Ha, Y., \& Kim, S. (2017). Public debt, corruption and sustainable economic growth. Sustainability, 9(3), 433. https://doi. org/10.3390/su9030433

Mauro, P. (1998). Corruption and the composition of government expenditure. Journal of Public Economics, 69(2), 263-279.

Montes, G. C., \& Paschoal, P. C. (2016). Corruption: What are the effects on government effectiveness? Empirical evidence considering developed and developing countries. Applied Economics Letters, 23(2), 146-150.

Panizza, U. (2008). Domestic and external public debt in developing countries (Discussion Paper No 188). United Nations Conference on Trade and Development. https://EconPapers.repec.org/ RePEc:unc:dispap:188.

Pareto, V. (1906). Manual of political economy. Milan.

Reinhart, C. M., \& Rogoff, K. S. (2010). Growth in a time of debt. American Economic Review, 100(2), 573-578.

Reinhart, C. M., \& Rogoff, K. S. (2011). From financial crash to debt crisis. American Economic Review, 101(5), 1676-1706.

Reinhart, C. M., \& Sbrancia, M. B. (2011, March). The liquidation of government debt (Working Paper 
16893). National Bureau of Economic Research. https://www.imf.org/external/np/seminars/ eng/2011/res2/pdf/crbs.pdf

Shleifer, A., \& Vishny, R. W. (1993). Corruption. The Quarterly Journal of Economics, 108(3), 599617. https://doi.org/10.2307/2118402

Tanzi, V., \& Chu, K. Y. (Eds.). (1998). Income distribution and high-quality growth. Mit Press.

Tanzi, V., \& Schuknecht, L. (1997). Reforming government: An overview of recent experience. European Journal of Political Economy, 13(3), 395-417.

Tarek, B. A., \& Ahmed, Z. (2017). Institutional quality and public debt accumulation: An empirical analysis. International Economic Journal, 31(3), 415-435.

Transparency International. (2019, January 29). Asia Pacific: Little to no progress on anti-corruption. https://www.transparency.org/news/feature/ asia_pacific_makes_little_to_no_progress_on_ anti_corruption
Verhoeven, M., Gupta, M. S., \& Tiongson, M. E. (1999, February 1). Does higher government spending buy better results in education and health care? International Monetary Fund. https://www.imf.org/en/Publications/WP/ Issues/2016/12/30/Does-Higher-GovernmentSpending-Buy-Better-Results-in-Education-andHealth-Care-2892\#: :text=Does\%20Higher\%20 Government\%20Spending\%20Buy\%20Better$\% 20$ Results $\% 20$ in $\% 20$ Education $\% 20$ and $\% 20$ Health\%20Care\%3F,-Author\%2FEditor\%3A\& text $=$ Summary $\% 3 \mathrm{~A}$,improves $\% 20$ education $\% 20$ and $\% 20$ health $\% 20$ indicators.

Wang, H., Huang, J., \& Li, H. (2017). Local government debt risk, fiscal expenditure efficiency and economic growth. In Proceedings of the Tenth International Conference on Management Science and Engineering Management (pp. 1565-1576). Springer.

World Bank. (2018). Government efficiency. https:// govdata360.worldbank.org/indicators/h5f135ad9 


\section{APPENDIX}

\section{Appendix 1}

List of advanced and emerging economics in this study

These are the 40 countries used in the study,

Advanced Economies:

Australia, Austria, Belgium, Canada, Denmark, France, Germany, Ireland, Israel, Italy, Japan, Netherland, Norway, Singapore, South Korea, Spain, Sweden, Switzerland, United Kingdom, United States.

Emerging Economies:

Brazil, Chile, China, Colombia, Egypt, India, Indonesia, Malaysia, Mexico, Nigeria, Pakistan, Philippines, Poland, Romania, Russian Federation, Saudi Arabia, South Africa, Thailand, Turkey, United Arab Emirates. 